\title{
Sexual Determination and Differentiation During Embryonic and Fetal Development of New Zealand Rabbit Females
}

\author{
Determinación y Diferenciación Sexual Durante el Desarrollo \\ Embrionario y Fetal de Conejos Hembras de Nueva Zelanda
}

\begin{abstract}
Lara Carolina Mario ${ }^{1}$; Jéssica Borghesi'; Adriana Raquel de Almeida da Anunciação'; Carla Maria de Carvalho Figueiredo Miranda $^{1}$; Amilton César dos Santos ${ }^{1}$; Phelipe Oliveira Favaron ${ }^{1}$; Daniela Martins dos Santos ${ }^{2}$; Daniel Conei ${ }^{3,4}$; Bélgica Vásquez ${ }^{5}$; Mariano del Sol ${ }^{3,6} \&$ Maria Angélica Miglino ${ }^{1}$
\end{abstract}

MARIO, L. C.; BORGHESI, J.; DA ANUNCIAÇÃO, A. R. A.; MIRANDA, C. M. C. F.; DOS SANTOS, A. C.; FAVARON, P. O.; DOS SANTOS, D. M.; CONEI, D.; VÁSQUEZ, B.; DEL SOL, M. \& MIGLINO, M. A. Sexual determination and differentiation during embryonic and fetal development of New Zealand rabbit females. Int. J. Morphol., 36(2):677-686, 2018.

SUMMARY: The aim of this study was to know the embryonic and fetal development of the female rabbit genital system (Oryctolagus cuniculus), describing its main phases and the moment of sexual differentiation. Eleven pregnant New Zealand female rabbits were used in different gestational phases. The day of coitus was determined as day 0 . For each stage a minimum of two animals was considered. The samples were obtained every two days from the ninth day post-coitus (dpc) until the $28^{\text {th }}$ dpc. The gestational period was divided in two: animals with undifferentiated sex (group 1) and animals with differentiated sex (group 2). The ages of embryos and fetuses were estimated through the crown-rump method. Subsequently, embryos and fetuses were dissected, fixed and processed to be embedded in paraffin (Histosec). The histological analysis was performed on sections stained with hematoxylin and eosin. Immunohistochemical analysis to determine sexual differentiation was performed on samples from the $16^{\text {th }}, 18^{\text {th }}$ and $28^{\text {th }}$ dpc. Desert Hedgehog (Dhh) and Indian Hedgehog (Ihh) primary antibodies, respectively, were used to identify cells of the male and female germinal epithelium. The immunohistochemical results showed that at the $16^{\text {th }} \mathrm{dpc}$, female sexual differentiation was evident, since positive expression of the Ihh protein was observed. Sexual differentiation was obtained through histological analysis on the $18^{\text {th }}$ dpc and through anatomical observation of the external genitalia on the $24^{\text {th }} \mathrm{dpc}$. Knowing the characteristics of the embryonic and fetal development of the female rabbit genital system as well as the moment of sexual differentiation make it possible to establish bases for future research that address the physiology and pathology of these organs. Thus, any alteration in the chain of events of sexual determination and differentiation must search for an explanation from the knowledge of the possible normal mechanisms affected.

KEY WORDS: Rabbit; Embryo; Fetus; Sexual differentiation.

\section{INTRODUCTION}

The study of the embryology of the female genital organs is of extreme importance for the knowledge of the physiology and the diseases that can affect it. In mammals, the development of urogenital organs begins in the intermediary mesoderm, and the gonadal primordium appears as a thickening of the coelomic epithelium in the medial phase of the mesonephros (Knospe, 2002; Hyttel et al., 2012).

In mice the period of sexual differentiation is already well known: they present on average 18 gestational days, and according to Munger \& Capel (2012) at 11.5 days the migration of the sex cells to the gonads occurs, but the female genital organs can still only be differentiated with the aid of a molecular biology analysis. The ovarian structure, necessary for oocyte development, is the essential stage for sex determination in this species (Nicholas et al., 2010; Kaufmann et al., 2011). The ovaries are elongated and homogeneous, thus allowing an analysis by means of light microscopy for differentiation between the species (Kaufmann et al.).

\footnotetext{
${ }^{1}$ School of Veterinary Medicine and Animal Science, Universidade de São Paulo, São Paulo, Brasil.

${ }^{2}$ Faculty of Animal Sciences and Food Engineering, Universidade de São Paulo, São Paulo, Brasil.

${ }^{3}$ Doctoral Program in Morphological Sciences, Faculty of Medicine, Universidad de La Frontera, Temuco, Chile.

${ }^{4}$ Department in Morphological Sciencies, Faculty of Science, Universidad San Sebastián, Puerto Montt, Chile.

${ }^{5}$ Faculty of Health Sciences, Universidad de Tarapacá, Arica, Chile.

${ }^{6}$ Centro de Excelencia en Estudios Morfológicos y Quirúrgicos (CEMyQ), Universidad de La Frontera, Temuco, Chile.
} 
MARIO, L. C.; BORGHESI, J.; DA ANUNCIAÇ̃̃O, A. R. A.; MIRANDA, C. M. C. F.; DOS SANTOS, A. C.; FAVARON, P. O.; DOS SANTOS, D. M.; CONEI, D.; VÁSQUEZ, B.; DEL SOL, M. \& MIGLINO, M. A. Sexual determination and differentiation during embryonic and fetal development of New Zealand rabbit females. Int. J. Morphol., 36(2):677-686, 2018.

The rabbit (Oryctolagus cuniculus) is a relevant animal model for experimental tests, mainly in the medical clinic and in regenerative medicine (Ferreira et al., 2005; Kamaruzaman et al., 2013). Due to its easy handling, low cost, and high reproductive index, studies are performed involving this animal model (Ajayi et al., 2005).

Fischer et al. (2012) used this animal to study the onset of human embryonic development given the similarity between their placentas. Fang et al. (2006) studied different cell lines derived from in vitro fertilization, parthenogenesis and somatic cells with nuclear transfer seeking to reach different cell lines and their behaviors for cellular therapies. Teramura et al. (2013) sought a new source of embryonic stem cells derived from immature primordial rabbit follicles for new treatments. Another paper that used rabbit as an animal model was by Abd-Allah et al. (2013), who chemically induced the formation of ovarian failure and then treated it with mesenchymal stem cells and thus observed[HML1] the pathway of these cells in this disease.

The female genital organs of rabbits have been described by Percy (1995), Fraser \& Girling (2009) and Couto (2002). Such authors have shown that the ovaries of rabbits are small and elongated; the female has two uterine horns, two uteri, and they enter the single vagina separately. The vagina is broad, with thin walls of the urethra opening to the cranial floor of the pelvis. The vulva is a common opening to the reproductive system and to the urinary system; it is cranial to the anus and surrounded by the inguinal glands.

Further studies of these organs in the area of embryology should be performed, given the great importance these animals have to research. The aim of this work is to study the embryonic development of the female genital organs, describing the main stages of embryology, as well as the moment of their sexual differentiation, thus contributing to new research in the development and functioning of the female reproductive system.

\section{MATERIAL AND METHOD}

Eleven female pregnant New Zealand rabbits were assayed at different gestational stages for observation of the embryonic and fetal development of the female genital tract. The animals came from the rabbit breeding sector of FZEA/ USP, and this research was approved by the research ethics committee of the University of São Paulo $\left(\mathrm{n}^{\circ}\right.$ : 13.11910.74.9). The females were placed for copula, and this day was indicated as day zero of the gestational period and then the accounting the gestational days were counted until the day of interest where the animals were euthanized for collection of the embryo or fetus.

The gestational period was divided into two groups: Group 1, animals with undifferentiated sex and Group 2, group with sexual differentiation. The ages of the embryos and fetuses were estimated by the crown-rump method, which consists of measuring the distance between the first nuchal vertebra and the last caudal vertebra and assessing the external characteristics as described by Evans \& Sack (1973) (Table I).

Table I. Definition of the two groups studied, age and crown of each animal.

\begin{tabular}{ccc}
\hline Group & $\begin{array}{c}\text { Gestacional } \\
\text { age }\end{array}$ & $\begin{array}{c}\text { Number of } \\
\text { animals }\end{array}$ \\
\hline 1 & 9 & 2 \\
& 10 & 2 \\
& 12 & 4 \\
2 & 14 & 4 \\
& 16 & 4 \\
& 18 & 4 \\
& 20 & 4 \\
& 22 & 3 \\
& 24 & 3 \\
& 25 & 3 \\
& 28 & 3 \\
\hline
\end{tabular}

Anatomical description. After identification of the gestational period, embryos and fetuses of Groups 1 and 2 were dissected to evaluate the anatomical structures of the female genitalia. The structures found were analyzed using a Nikon SMZ 645/660 stereo microscope and photodocumented.

Histological analysis. To perform the histological studies, some embryos and fetuses from each group were fixed in $4 \%$ paraformaldehyde solution for 48 hours. After fixation, the material was washed in phosphate buffer, followed by dehydration in a series of increasing ethanol concentrations (70 to $100 \%$ ), followed by diaphanization in xylol, then embedded in paraffin-like (Histosec) [HML2] (Tolosa et al., 2003).

The blocks were submitted to microtomy in an automatic microtome (Leica, RM2165, Germany), obtaining cuts of $5 \mathrm{~mm}$, which were adhered in histological slides and left in an oven at $60^{\circ} \mathrm{C}$. After the cuts were deparaffinized, they were stained by routine techniques of tissue staining, using hematoxylin and eosin. 
MARIO, L. C.; BORGHESI, J.; DA ANUNCIAÇÃO, A. R. A.; MIRANDA, C. M. C. F.; DOS SANTOS, A. C.; FAVARON, P. O.; DOS SANTOS, D. M.; CONEI, D.; VÁSQUEZ, B.; DEL SOL, M. \& MIGLINO, M. A. Sexual determination and differentiation during embryonic and fetal development of New Zealand rabbit females. Int. J. Morphol., 36(2):677-686, 2018.

Afterwards the slides were analyzed and the morphological characteristics found were photodocumented in a Leica ICC50 HD microscope.

Immunohistochemistry. Rabbit gonads were cut at gestational ages of 16, 18 and 28 days using the markers Desert hedgehog (Dhh) and Indian hedgehog (Ihh) to identify germ cells and proliferation respectively. Positive control of this reaction was done using ovary from adult rabbits to determine if the antibodies referred to above were manifested in the control group.

The histological sections were dewaxed in xylol, and in the second passage of $100 \%$ ethanol the cuts had the endogenous peroxidase blocked in $3 \% \mathrm{H}_{2} \mathrm{O}_{2}$ in $100 \%$ ethanol for 20 minutes. These cuts were then hydrated in decreasing concentrations of ethanol, and then antigenic recovery was performed with $0.1 \mathrm{M}$ citrate buffer $\mathrm{pH} 6.0$ in a steamer for 30 minutes. The Cell \& Tissue Staining HRP-DAB System kit (R \& D Systems, Goat Kit, CTS008) was used. Ihh (C-15, sc-1196, Santa Cruz Biotechnology, polyclonal) and Dhh (N-17, sc-33940, Santa Cruz Biotechnology, polyclonal) primary antibodies were incubated, diluted $1: 100$ in a humid chamber at $37^{\circ} \mathrm{C}$ for 90 minutes. The negative control was given by the completion of the entire technique, but without the incubation of the primary antibodies. Positive control of this reaction was done using ovary from adult rabbits to determine if the antibodies referred to above were manifested in the control group.

\section{RESULTS}

External characteristics of embryos. Embryos and fetuses had external characteristics that made it possible to separate these animals according to their specific gestational ages
(Table II). Group 1, comprised only of embryos and did not present evident sexual differentiation; therefore, the organ responsible for the gamete formation in these individuals was called gonad. Group 2 was comprised of embryos and fetuses where sexual differentiation was evident.

\section{Morphological description of embryos and fetuses}

Group 1: The embryonic development of the female reproductive tract begins in the intermediate mesoderm in the neuron period. The urogenital crest materializes[HML3] from the intermediate mesoderm, which later gives rise to the male and female gonads (Figs. 1A to D). In the stages on 9,10 and 12 gestational days, it was not yet possible to observe the formation of the gonad and thus to distinguish the sex of the embryos. However, on day 14, it was already possible to observe the beginning of gonad formation, the location of which was cranial to the mesonephros (Figs. $1 \mathrm{E}$ and F).

Group 2: On the $16^{\text {th }}$ gestational day, it was still not possible to observe the sexual differentiation in this species (Fig. 2A). Histologically, the primordial gonad was visible, still connected to the mesonephros and showing signs of sexual differentiation apparently for females, since the stromal cells presented a homogenous distribution without morphological evidence of initial formation of seminiferous tubules (Figs. $2 \mathrm{~B}$ to $\mathrm{D})$.

It was not yet possible to differentiate the sex of this animal (Figs 3A and 3H) externally at 18 and 20 gestational days, but microscopically from the $18^{\text {th }}$ gestational day, the structures found in the gonad already had ovary characteristics, and therefore it was possible observe primordial follicles in the epithelial region of the ovarian tissue, which did not present corticomedullary division (Figs. $3 \mathrm{D}$, $\mathrm{E}$ and $\mathrm{J})$. The other components of the female reproductive system were also present (Figs 3 B, C, F, G, I, K and L).

Table II. definition of the two age groups and Crown-rump and external characteristics.

\begin{tabular}{|c|c|c|c|}
\hline Group & Gestacional age & Mean Crown-rump $(\mathrm{cm})$ & External characteristics \\
\hline \multirow[b]{4}{*}{1} & 9 & - & Embryonic button. \\
\hline & 10 & - & Appearance of the 3 branchial arch, bud of the thoracic and caudal limb. \\
\hline & 12 & 0.8 & C shaped embryo, acoustic meatus formation, presence of hand plaque. \\
\hline & 14 & 1.4 & Pigmented eyes, pina in cone shape, groove between digits. \\
\hline \multirow{7}{*}{2} & 16 & 1.9 & Intestine herniate d to the umbilical cord, closed nostrils with epithelial cap. \\
\hline & 18 & 2.7 & Eyelids partially cover the eyes. \\
\hline & 20 & 3.9 & Fused eyelids and claws. The intestine returns to the abdominal cavity. \\
\hline & 22 & 4.4 & Pina well developed and directed caudally. \\
\hline & 24 & 7.0 & Sexual differentiation through the external genitalia. \\
\hline & 25 & 6.0 & External features developed. \\
\hline & 28 & 8.6 & External features developed. \\
\hline
\end{tabular}



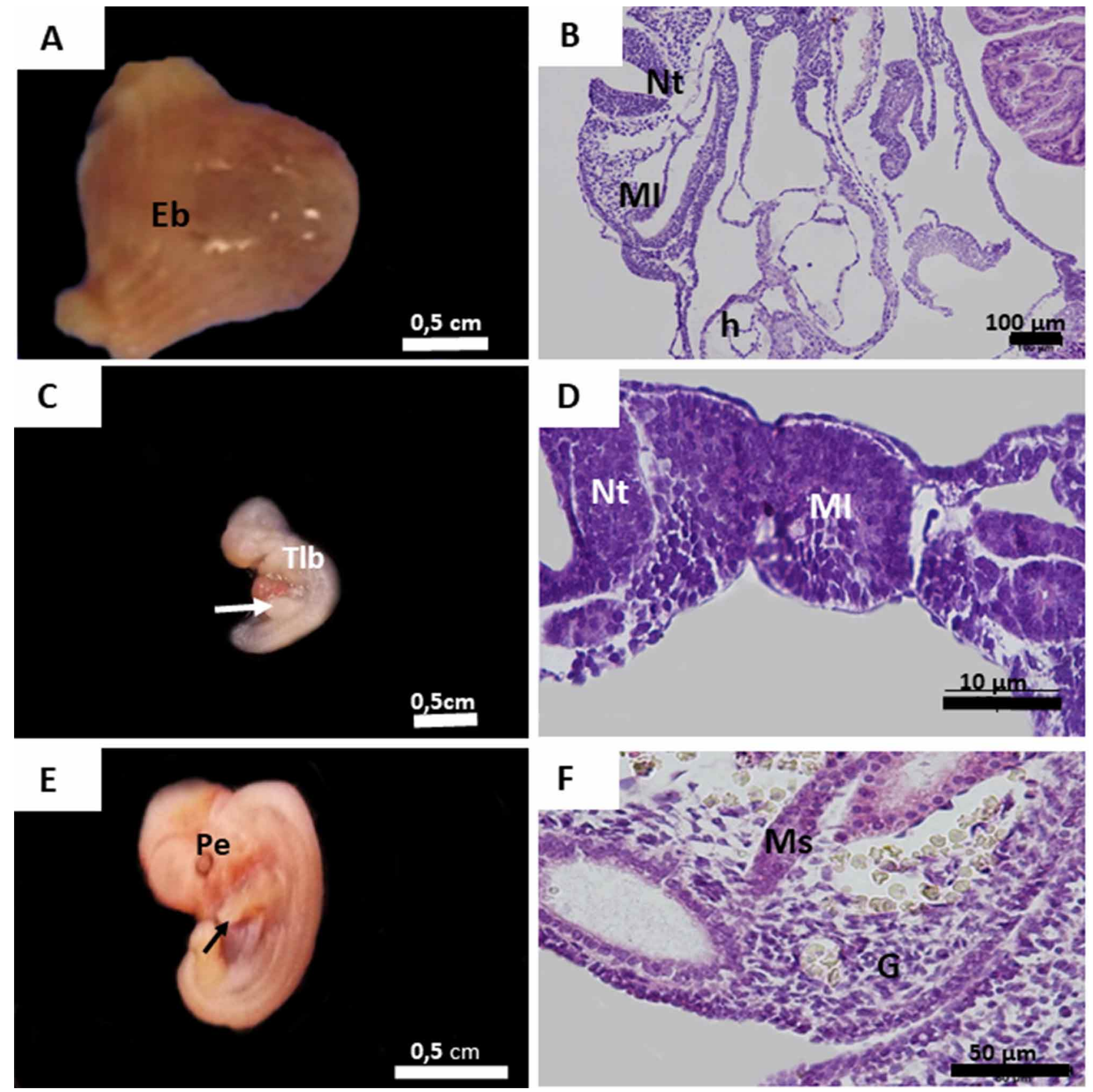

Fig. 1. Photomicrograph of the rabbit embryo. In the embryonic bud of rabbit (Eb) with 9 gestational days. In B, histology of the embryo with 9 days, evidencing the neural tube (Nt), the intermediate mesoderm (MI) and the beginning of the heart formation (h). In $\mathrm{C}$ and $\mathrm{D}$, embryo with 10 gestational days, note in C, appearance of the thoracic bud (Tlp) and pelvic (arrow). In D, the presence of neural tube (Nt) and intermediate mesoderm (MI) that will form the urogenital system. In E and F, photomicrography of rabbit embryo with 14 gestational days is observed. In $\mathrm{E}$ the embryo presents the pigmented eyes (Pe) and interdigital membranes (arrow). In $\mathrm{F}$, observe the beginning of the formation of the gonoda $(\mathrm{G})$ cranially to the mesonephro (Ms).

At 24 and 28 gestational days, the fetuses analyzed (Fig. 4A) were already at the end of the development, the sexual differentiation could be seen for the first time at 24 gestational days through external anatomical characteristics, observing the triangular shape of the opening (Fig. 4B). The structures of the internal female genitalia were already complete and formed, leaving only their growth. 

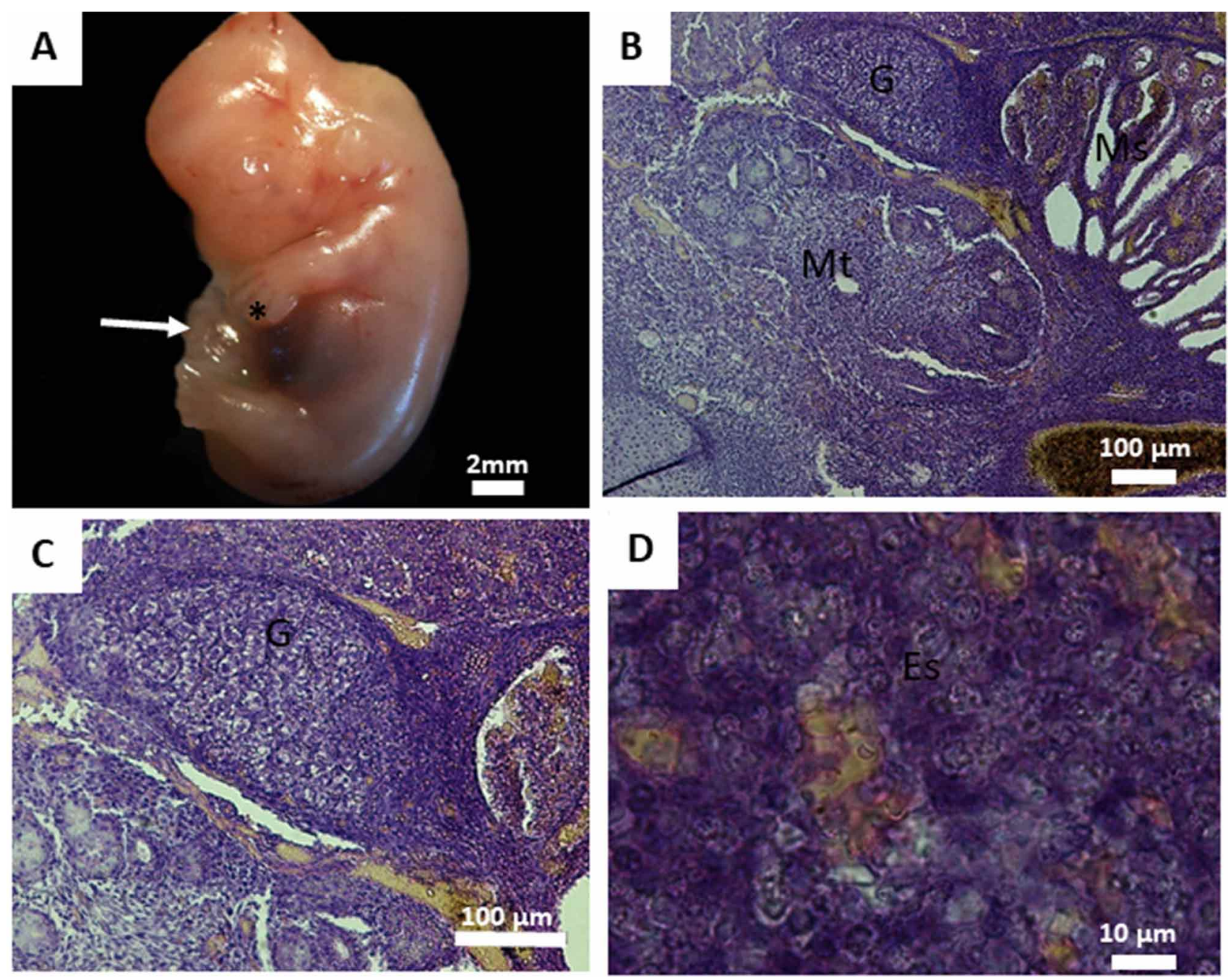

Fig. 2. Photomicrograph of rabbit embryo at 16 gestational days. In A, embryo evidencing the herniation of the intestine to the umbilical cord (arrow), and the interdigital membranes $(*)$. B, gonad $(\mathrm{G})$ cranially attached to the mesonephro (Ms) with onset of sexual differentiation. In $\mathrm{C}$ and $\mathrm{D}$ gonad (G). Coloration, Hematoxylin and Eosin.

The female gonads, the ovaries, were elliptical in shape, located in the dorsal portion of the abdomen near the regions of the uterine horns. Internally the ovary is covered by a layer of simple cuboidal epithelium, the germinal epithelium (Fig. $4 \mathrm{C}$ and K). At this stage it was not possible to differentiate cortical and medullar regions, only the primordial follicles were evident in the region of the germinative cells (Fig. 4C).

In sequence, the uterine tubes were identified in its three infundibulum parts, which opened in the peritoneal cavity near the ovary. The ampoule was the medial and more extensive portion of the uterine tube, and presented a curvature on the ovary. The isthmus presented a structure called intramural in its extremity, which crossed the uterine wall opening inside this organ. Internally the uterine tubule had a columnar epithelium, a muscular layer and a serous layer (Figs. $4 \mathrm{D}$ and L).

Rabbits have two uteri, which implies two cervixes opening separately into a single vagina (Fig. 4 E). Internally the uterus was formed by cubic epithelium and connective tissue, by a muscular layer and by a serous one. In the sequence, the cervix, the lower cylindrical portion of the uterus, had a simple mucus-secreting epithelium, followed by a urethra which histologically showed a pavement epithelium and connective tissue (Figs. $4 \mathrm{~F}$ and $\mathrm{N}$ ). 

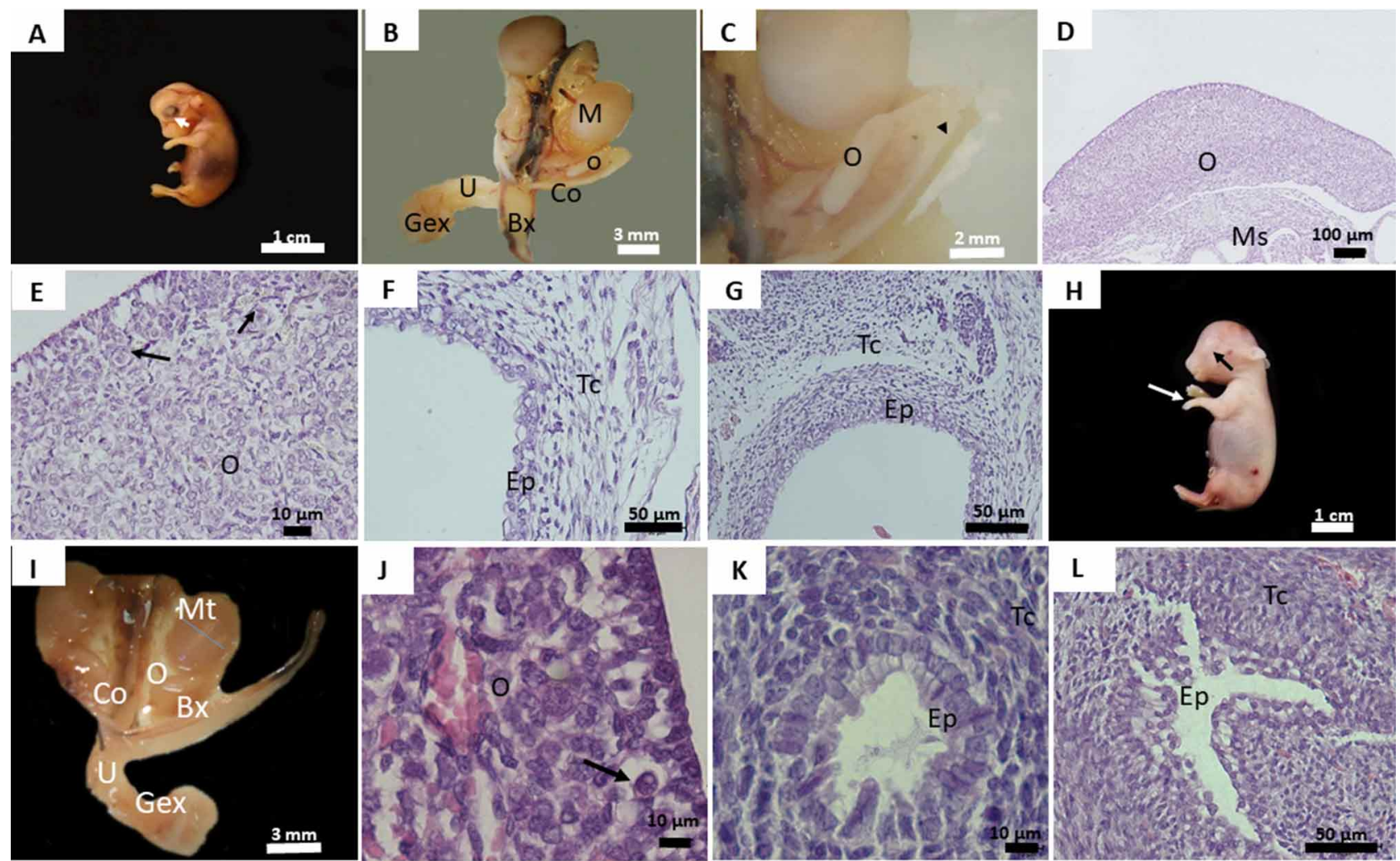

Fig. 3. Gross description of the female genital organs of 18 and 20 gestational days. In A, rabbit embryo with 18 days, showing that the eye is pigmented (arrow). In B, urogenital system showing the syntopy of the organs, metanephric (MT), Ovary (O), uterine horn (Co), bladder $(\mathrm{Bx})$, urethra $(\mathrm{U})$ and external genitalia $(\mathrm{Gex})$. C, ovary $(\mathrm{O})$, uterine tubes (arrow). In D and E, histology of the embryo of 18 days, evidencing the ovary $(\mathrm{O})$, parallel to the mesonephro (ms), already differentiated evidencing the primordial follicles (arrow). F, urethra, showing epithelium (PE) and connective tissue (CT). G, cervix, where epithelium (PE) and connective tissue (CT) can be observed. In H, embryo with 30 days with the eyelids (black arrow) and claws (white arrow) already fused and the intestine already returned to the abdominal cavity. I, synapse of the urogenital system, metanephros (Mt) Ovary (O), as uterine (Co), bladder (Bx), urethra (U) and external genitalia (Gex) were observed. J, histology of the 20-day embryo where the ovary (O) can be seen, with the primordial follicles (arrow). K, uterine horn showing epithelium (PE) and connective tissue (CT). L, urethra showing epithelium (PE) and connective tissue (CT).

The vagina had a muscular tube, communicating with the vestibule caudally and with the cervix cranially. Histologically it was a stratified paved epithelium (Figs. 4G and $\mathrm{O}$ ).

The immunohistochemical assay revealed a distinction in the gonadal differentiation in the various phases of ovary development in New Zealand rabbits. In the 14day embryos, no positive marking was observed for Ihh or Dhh, demonstrating that at this age the gonad was still undifferentiated (Fig. 5A). At 16 days, cells with Ihh labeling were first noted, showing that even the undifferentiated gonad was already expressing this protein (Fig. 5B). At 18 gestational days the ovary could be observed histologically in this species, and through immunohistochemistry we confirmed only the positive marking on the germinal epithelium and the paramesonephric ducts (Figs. $5 \mathrm{C}$ and D). On the $28^{\text {th }}$ day of gestation - the final phase of embryonic development - positive markings were observed throughout the ovary (Figs. 5E and F), and in adult rabbits positive markings were also observed for the Ihh protein in this organ. In the adult ovary, all the germinal epithelia presented positive marking (Fig.s $5 \mathrm{G}$ to I).

\section{DISCUSSION}

The rabbit embryos and fetuses in this work were divided according to the sexual differentiation in this species. At 16 gestational days, for the first time there was sexual differentiation. Many studies in several animals seek this 

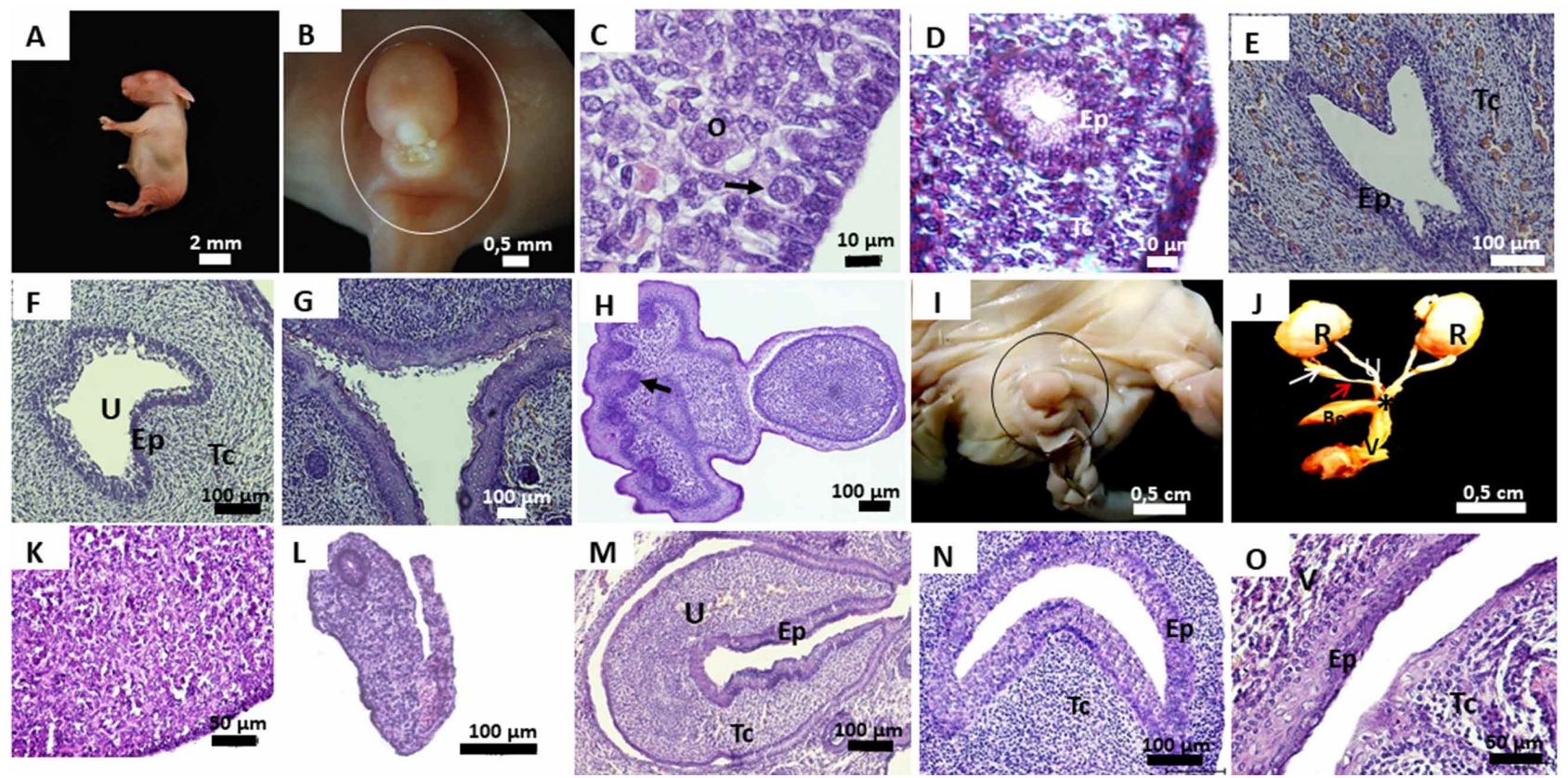

Fig. 4. Photomicrography of rabbit fetus with 24 days. In A and B, observe the differentiation through the external genitalia (halo). In C, ovary $(\mathrm{O})$ cells and primordial follicles (arrow). D, uterine horn, with epithelium (Ep) and connective tissue (Tc). E, cervix with epithelium (Ep) and connective tissue (Tc). In F, urethra. G, vagina, epithelium (Ep) and connective tissue. H, genital opening, showing the rectal glands (arrow). In I and J, fetus with 28 days gestational evidencing the genital opening and differentiation in females (halo). K, ovary (O) and primordial follicles (arrow). L, uterine horn, showing epithelium (PE) and connective tissue (CT). In M, urethra, with epithelium (PE) and connective tissue (CT). In N, cervix with epithelium (PE) and connective tissue (CT). O, vagina, showing epithelium (PE) and connective tissue (CT).

data, especially studies that need to know the animal's sex in advance (Wilhelm et al., 2007). It is known that the sex of the embryo is determined from the time of fertilization: the XY heterogamous chromosomes determine males and homorganic females (Wilhelm et al.). However, the process of sexual differentiation occurs after this phase, having a specific day for each animal species. The germ cells initially located in the wall of the yolk sac migrate through ameboid movements through the dorsal mesentery to form the gonad, resulting in gonadal differentiation (Tam \& Snow, 1981; Kruman et al., 2002).

The period of sexual differentiation varies among animal species. In mice, sexual differentiation occurs at 13 gestational days (Theiler, 1989). This period corresponds to approximately $50 \%$ of the gestational period, which in rabbits would be equivalent to approximately 16 gestational days. In this study, the beginning of the differentiation period with primordial oogonia and follicles was already observed at 16 gestational days. It is noteworthy that the female shows a later sexual development than the males (Theiler). In mammals, the primordial follicles are undifferentiated until the period of sexual maturation. For the formation of follicles, primitive sexual cords are formed from the coelomic epithelium; these cords form an ovarian network with oogonia and surrounded by the primordial follicles (DeFalco \& Capel, 2009).

The other structures of the female reproductive system were observed at 18 gestational days, structures that are formed later than the gonad (Wilhelm et al.). The tubular structures of the female reproductive system derive from the paramesonephric ducts and serve to take the oocyte to the implantation site in the adult female (Miller \& Gore, 2002).

Analyzing the gonadal differentiation through the Ihh protein present only in females, at 16 days the onset of gonadal differentiation confirmed the data presented by the histological analysis, which offered indications of the sexual differentiation of the females. And at 18 gestational days the age at which sexual differentiation occurs in this species could be confirmed. This protein is involved in oocyte maturation and, therefore, it is expressed from the embryonic period when the germinal epithelium begins to appear until the adult stage, where the oocytes properly mature (Liu et al., 2015). 

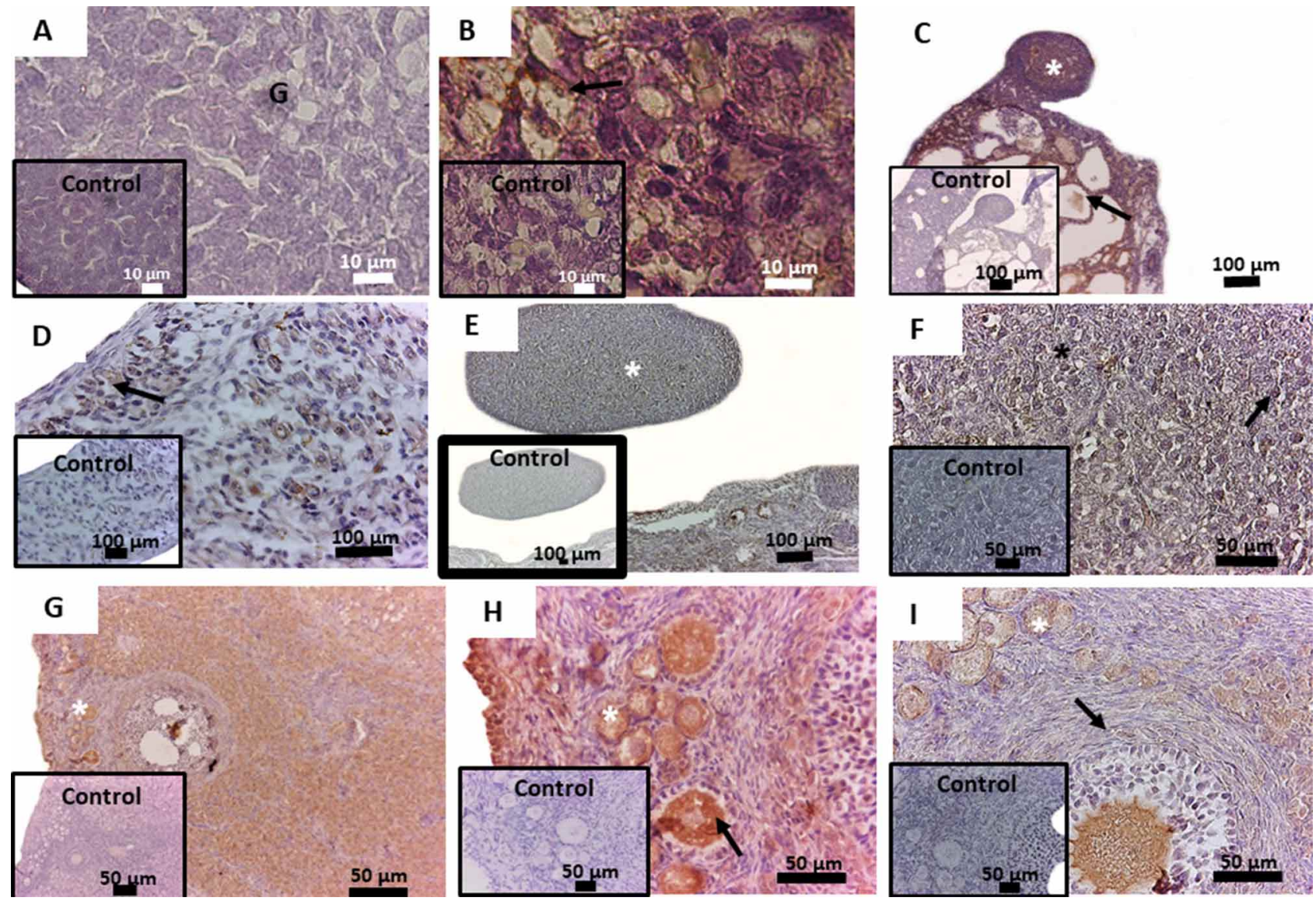

Fig. 5. Immunohistochemical analysis of New Zealand rabbit gonads and ovaries. In A, undifferentiated gonadal (G) in rabbit embryos at 14 days, without positive marking. In B, beginning of gonadal differentiation in rabbit embryos at 16 days, in this phase there was positive labeling for Ihh in some cells (arrow). In C, rabbit embryo with 16 gestational days, where we can observe a positive mark for Ihh in the gonad $\left(^{*}\right)$ and in the mesonephro (arrow). In D, ovary of rabbit fetuses with 18 days, where it was possible to observe positive marking in the germinal epithelium (arrow). Positive marking for Ihh in ovary of fetuses of rabbits with 28 days of gestation (*), it was also possible to observe positive marking for the primordial follicles (arrow). In G, H, and I, adult rabbit ovary where it was possible to observe positive labeling for Ihh in the germinative epithelium in primordial follicles (*) and in growing follicles (arrow).

From the $24^{\text {th }}$ gestational day, the external genitalia of rabbits can be differentiated. In females the genital tubercle grows a little, forming the clitoris; the urogenital pleats do not fuse and give rise to the small vaginal lips and the labio-scrotal eminences[HML4], which do not fuse, giving rise to the big vaginal lips. This data is of extreme importance, as it contributes to the large-scale production of these animals, particularly when it comes to selecting one of the sexes for scientific research (Healey et al., 2003).

The rabbit is widely used as a model for the most diverse studies involving the reproductive system. A study by Foote \& Carney (2000) evaluated the toxicity of semen as well as diseases in the female and male reproductive system. Abd-Allah et al. assessed the action of the mesenchymal cells in chemically induced ovarian failure. This animal is also an excellent model for polycystic ovarian syndrome as described by Oakley et al. (2011).

These articles help support studies of the genitalia in adult rabbits, confirming that this animal is an excellent model for reproductive research. Nevertheless, studies on the embryonic development of the genital organs are important for a deeper understanding of this system. However, the main contribution of this work is to provide parameters of rabbit organogenesis in drug research in order to verify whether teratogenic effects occur due to the action of harmful substances on the mother and consecutively to the developing fetus through the transplacental route (Brannen et al., 2011) in addition to assisting with gonadal malformation research in humans. 
In conclusion, ascertaining the importance of this animal in the various studies, we sought to determine the sexual differentiation and characterization of the main structures of female embryonic development, from which it was demonstrated that at 16 days the gonadal differentiation was observed through the immunohistochemical analysis and confirmed by the positive labeling of the Ihh protein. Moreover, at 18 gestational days the histological analysis showed, for the first time, sexual differentiation, in addition to the other organs that comprise this system. Finally, it was verified that the differentiation of the external genitalia occurred at 24 gestational days.

MARIO, L. C.; BORGHESI, J.; DAANUNCIAÇÃO, A. R. A.; MIRANDA, C. M. C. F.; DOS SANTOS, A. C.; FAVARON, P. O.; DOS SANTOS, D. M.; CONEI, D.; VÁSQUEZ, B.; DEL SOL, M. \& MIGLINO, M. A. Determinación y diferenciación sexual durante el desarrollo embrionario y fetal de conejos hembras de Nueva Zelanda. Int. J. Morphol., 36(2):677-686, 2018.

RESUMEN: El objetivo de esta investigación fue conocer el desarrollo embrionario y fetal del sistema genital femenino de conejo (Oryctolagus cuniculus), describiendo sus principales fases y el momento de la diferenciación sexual. Se utilizaron 11 conejos hembras gestantes neozelandesas, en diferentes fases gestacionales. El día del coito se determinó como día 0. Para cada etapa fue considerado un mínimos de dos animales. Las muestras fueron obtenidas cada dos días, a partir del noveno día post-coito (dpc) hasta el $28 \mathrm{dpc}$. El periodo gestacional fue dividido en dos: animales con sexo indiferenciado (grupo 1) y, animales con sexo diferenciado (grupo 2). Las edades de los embriones y los fetos fueron estimadas a través del método de crown-rump. Posteriormente, embriones y fetos fueron disecados, fijados y procesados para su inclusión en parafina (Histosec). El análisis histológico se realizó en secciones teñidas con Hematoxilina y Eosina. El análisis inmunohistoquímico para determinar la diferenciación sexual fue realizado en muestras de 16, 18 y 28 dpc. Para identificar células del epitelio germinativo masculino y feminino se utilizaron los anticuerpos primarios Desert Hedgehog (Dhh) e Indian Hedgehog (Ihh), respectivamente. Los resultados inmunohistoquímicos mostraron que a los $16 \mathrm{dpc}$ se evidenció diferenciación sexual femenina, ya que se observó expresión positiva de la proteína Ihh. La diferenciación sexual, a través del análisis histológico fue obtenida a los 18 dpc y a través de la observación anatómica de los genitales externos a los $24 \mathrm{dpc}$. Conocer las características del desarrollo embrionario y fetal del sistema genital femenino de conejo, así como, el momento de la diferenciación sexual, permiten sentar bases para futuras investigaciones que aborden la fisiología y patología de estos órganos. Así, cualquier alteración en la cadena de eventos de la determinación y diferenciación sexual deberá buscar una explicación a partir del conocimiento de los posibles mecanismos normales afectados.

PAlabRas ClaVE: Conejo, embrión, feto, diferenciación sexual.

\section{REFERENCES}

Abd-Allah, S. H.; Shalaby, S. M.; Pasha, H. F.; El-Shal, A. S.; Raafat, N.; Shabrawy, S. M.; Awad, H. A.; Amer, M. G.; Gharib, M. A.; El Gendy, E. A.; Raslan, A. A. \& El-Kelawy, H. M. Mechanistic action of mesenchymal stem cell injection in the treatment of chemically induced ovarian failure in rabbits. Cytotherapy, 15(1):64-75, 2013.

Ajayi, F. O.; Balogun, O. O.; Ovuru, S. S. \& Mgbere, O. O. Reproductive performance of rabbits fed maize-milling waste based diets. Afr. $J$. Biotechnol., 4(5):439-43, 2005.

Brannen, K. C.; Fenton, S. E.; Hansen, D. K.; Harrouk, W.; Kim, J. H. \& Shuey, D. Developmental toxicology: new directions workshop: refining testing strategies and study designs. Birth Defects Res. B Dev. Reprod. Toxicol., 92(5):404-12, 2011.

Couto, S. E. R. Criação e Manejo de Cobaias. In: Andrade, A.; Pinto, S. C. \& Oliveira, R. S. (Eds.). Animais de Laboratório: Criação e Experimentação. Rio de Janeiro, Editora Fio Cruz, 2002.

DeFalco, T. \& Capel, B. Gonad morphogenesis in vertebrates: divergent means to a convergent end. Ann. Rev. Cell Dev. Biol., 25:457-82, 2009.

Evans, H. E. \& Sack, W. O. Prenatal development of domestic and laboratory mammals: growth curves, external features and selected references. Zentralbl. Veterinarmed. C., 2(1):11-45, 1973.

Fang, Z. F.; Gai, H.; Huang, Y. Z.; Li, S. G.; Chen, X. J.; Shi, J. J.; Wu, L.; Liu, A.; Xu, P. \& Sheng, H. Z. Rabbit embryonic stem cell lines derived from fertilized, parthenogenetic or somatic cell nuclear transfer embryos. Exp. Cell Res., 312(18):3669-82, 2006.

Ferreira, L. M.; Hochman, B. \& Barbosa, M. V. J. Modelos experimentais em pesquisa. Acta Cir. Bras., 20(2):28-34, 2005.

Fischer, B.; Chavatte-Palmer, P.; Viebahn, C.; Navarrete Santos, A. \& Duranthon, V. Rabbit as a reproductive model for human health. Reproduction, 144(1):1-10, 2012.

Foote, R. H. \& Carney, E. W. The rabbit as a model for reproductive and developmental toxicity studies. Reprod. Toxicol., 14(6):477-93, 2000.

Fraser, M. \& Girling, S. Rabbit Medicine and Surgery for Veterinary Nurses. Oxford, Wiley-Backwell, 2009.

Healey, S.; Tan, S. L.; Tulandi, T. \& Biljan, M. M. Effects of letrozole on superovulation with gonadotropins in women undergoing intrauterine insemination. Fertil. Steril., 80(6):1325-9, 2003.

Hyttel, P.; Sinowatz, F. \& Vejlsted, M. Embriologia Veterinária. Rio de Janeiro, Elsevier, 2012.

Kamaruzaman, N. A.; Kardia, E.; Kamaldin, N.; Latahir, A. Z. \& Yahaya, B. H. The rabbit as a model for studying lung disease and stem cell therapy. Biomed. Res. Int., 2013:691830, 2013.

Kaufmann, L. T.; Gierl, M. S. \& Niehrs, C. Gadd45a, Gadd45b and Gadd45g expression during mouse embryonic development. Gene Expr. Patterns, 11(8):465-70, 2011.

Knospe, C. Periods and stages of the prenatal development of the domestic cat. Anat. Histol. Embryol., 31(1):37-51, 2002.

Kruman, I. I.; Kumaravel, T. S.; Lohani, A.; Pedersen, W. A.; Cutler, R. G.; Kruman, Y.; Haughey, N.; Lee, J.; Evans, M. \& Mattson, M. P. Folic acid deficiency and homocysteine impair DNA repair in hippocampal neurons and sensitize them to amyloid toxicity in experimental models of Alzheimer's disease. J. Neurosci., 22(5):175262, 2002.

Liu, C.; Peng, J.; Matzuk, M. M. \& Yao, H. H. Lineage specification of ovarian theca cells requires multicellular interactions via oocyte and granulosa cells. Nat. Commun., 6:6934, 2015.

Miller, B, H. \& Gore, A. C. N-Methyl-D-aspartate receptor subunit expression in GnRH neurons changes during reproductive senescence in the female rat. Endocrinology, 143(9):3568-74, 2002.

Munger, S. C. \& Capel, B. Sex and the circuitry: progress toward a systems-level understanding of vertebrate sex determination. Wiley Interdiscip. Rev. Syst. Biol. Med., 4(4):401-12, 2012. 
MARIO, L. C.; BORGHESI, J.; DA ANUNCIAÇÃO, A. R. A.; MIRANDA, C. M. C. F.; DOS SANTOS, A. C.; FAVARON, P. O.; DOS SANTOS, D. M.; CONEI, D.; VÁSQUEZ, B.; DEI SOL, M. \& MIGLINO, M. A. Sexual determination and differentiation during embryonic and fetal development of New Zealand rabbit females. Int. J. Morphol., 36(2):677-686, 2018.

Nicholas, C. R.; Haston, K. M. \& Pera, R. A. R. Intact fetal ovarian cord formation promotes mouse oocyte survival and development. B. $M$. C. Dev. Biol., 10:2, 2010.

Oakley, O. R.; Frazer, M. L. \& Ko, C. Pituitary-ovary-spleen axis in ovulation. Trends Endocrinol. Metab., 22(9):345-52, 2011.

Percy, D. The biology of the laboratory rabbit. Can. Vet. J., 36(10):646-7, 1995.

Tam, P. P. \& Snow, M. H. Proliferation and migration of primordial germ cells during compensatory growth in mouse embryos. J. Embryol. Exp. Morphol., 64:133-47, 1981.

Teramura, T.; Sugimoto, H.; Frampton, J.; Kida, Y.; Nakano, M.; Kawakami, M.; Izumi, H.; Fukunaga, N.; Onodera, Y.; Takehara, T.; Fukuda, K. \& Hosoi, Y. Generation of embryonic stem cell lines from immature rabbit ovarian follicles. Stem Cells Dev., 22(6):928-38, 2013.

Theiler, K. The house mouse: atlas of mouse development. Berlin, Springer Verlag, 1989.

Tolosa, E. M. C.; Rodrigues, C. J.; Behmer, O. A. \& Neto, A. G. F. Manual de Técnicas para Histologia Normal e Patológica. $2^{\mathrm{a}}$ ed., São Paulo, Manole, 2003.

Wilhelm, D.; Palmer, S. \& Koopman, P. Sex determination and gonadal development in mammals. Physiol. Rev., 87(1):1-28, 2007.
Corresponding author:

Lara Carolina Mario

School of Veterinary Medicine and Animal Science

Universidade de São Paulo

São Paulo

BRAZIL

\section{E-mail: laracarolina-mario@hotmail.com}

Received: 09-01-2018

Accepted: 28-02-2018 